\title{
Medicinal plant extract (Ankaferd Blood Stopper) application in deep tissue injuries in rats: histopathological investigation of the effect on regional and systemic tissues
}

\author{
Bitkisel özlü Ankaferd Blood Stopper'in sıçanlarda derin dokulara uygulamada \\ bölgesel ve sistemik dokulara etkilerinin histopatolojik olarak incelenmesi
}

\author{
Mehmet OKUMUŞ, ${ }^{1}$ Kasım Zafer YÜKSEL, ${ }^{2}$ Davut ÖZBAĞ,${ }^{3}$ Harun ÇIRALIK, ${ }^{4}$ \\ Zeki YILMAZ, ${ }^{2}$ Yakup GÜMÜŞALAN, ${ }^{3}$ Vedat BAKAN, ${ }^{5}$ Ali Murat KALENDER ${ }^{6}$
}

\section{BACKGROUND}

This study was planned to evaluate both the histopathological changes under light microscope as well as the systemic organ effects following application of Ankaferd Blood Stopper $^{\circledR}$ (ABS) (a mixture of five plant extracts) in an animal model of deep tissue hemorrhage.

\section{METHODS}

A total of 50 Wistar Albino rats were divided into five groups of 10 rats each. The rats underwent femoral vein puncture and were treated with ABS tampon, ABS spray, or Surgicel, and one group was left untreated. After two weeks, each group underwent partial tissue excision from the same femoral region as well as from the brain, heart, kidney, and liver.

\section{RESULTS}

The specimens from all groups were obtained from the femoral region after two weeks and evaluated under light microscope. The light microscope revealed no histopathological changes in neurovascular structures or in deep connective tissues in any of the groups.

\section{CONCLUSION}

ABS provided hemostasis and was observed to stop bleeding. There were no histopathological changes at the tissue level and no pathological effects in other organs tissues under light microscope, and the remote organ tissue remained clear.

Key Words: Ankaferd blood stopper; deep tissue injury; hemostasis.

\section{AMAC}

Bu çalışmada, Ankaferd Blood Stopper ${ }^{\circledR}$ (ABS) (beş bitki özü karışımı), bir hayvan modelinde derin doku kanamalarına uygulandığında, histopatolojik değişikliklerin ve sistemik organ etkilerinin 1 şı mikroskobu altında değerlendirilmesi planland1.

\section{GEREC VE YÖNTEM}

Toplamda 50 adet Wistar Albino sıçanlar her birinde 10'ar adet olmak üzere 5 gruba ayrıldı. Sıçanlarda femoral ven delinerek ABS tampon, ABS sprey, Surgicel ile tedavi edildi, bir grup hiç tedavi almadi. İki hafta sonra her gruptan aynı femoral bölgeden ve aynı zamanda beyin, kalp, böbrek ve karaciğerden kısmi doku alındı.

\section{BULGULAR}

İki hafta sonra tüm gruplarda femoral bölgeden elde edilen örnekler 1şık mikroskobu ile değerlendirildi. Tüm gruplarda nörovasküler yapılarda veya derin bağ dokularında 1 şık mikroskobu incelemesinde herhangi bir histopatolojik değişiklik ortaya çıkmadı.

SONUÇ

Ankafer Blood Stopper'in hemostazı sağladığı ve kanamayı durdurduğu gözlemlendi. Işık mikroskobunda doku düzeyinde histopatolojik değişiklikler ve diğer organlarda patolojik etkiler yoktu, uzak organ dokuları temizdi.

Anahtar Sözcükler: Ankaferd kan durdurucu; derin doku yaralanmas1; hemostaz.
Departments of ${ }^{1}$ Emergency Medicine, ${ }^{2}$ Neurosurgery,${ }^{3}$ Anatomy, ${ }^{4}$ Pathology, ${ }^{5}$ Pediatric Surgery, ${ }^{6}$ Orthopedics and Traumatology, Sutcu Imam University Faculty of Medicine, Kahramanmaras, Turkey.
Sütçü İmam Üniversitesi Tıp Fakültesi, ${ }^{1}$ Acil Tıp Anabilim Dalı, ${ }^{2}$ Beyin ve Sinir Cerrahisi Anabilim Dal, ${ }^{3}$ Anatomi Anabilim Dal, ${ }^{4}$ Patoloji Anabilim Dal, ${ }^{5}$ Cocuk Cerrahisi Anabilim Dalı, ${ }^{6}$ Ortopedi ve Travmatoloji Anabilim Dalı, Kahramanmaraş. 
Approximately one-half of the deaths in trauma are associated with hemorrhagic shock. ${ }^{[1]}$ The first step in managing trauma patients is to establish a secure airway, immobilize the cervical column, and obtain adequate breathing and circulation; control of hemorrhage is the second crucial step. ${ }^{[2]}$ Many methods and pharmacological agents are being used to stop or control the hemorrhage that could end mortally. The accustomed hemostasis comprises vasoconstriction and clot formation, which leads to cessation of bleeding. Hemostasis is achieved through the activation of platelets and the coagulation cascade. ${ }^{[3]}$

In cases of trauma including major arteries and veins or internal organs, it is essential to control the hemorrhage in a timely manner. The vascular endothelium plays a pivotal role in the regulation of hemostasis. After the occurrence of vascular injury, endothelial cells limit clot formation to the areas where hemostasis is needed to restore vascular integrity. ${ }^{[4]}$

Ankaferd Blood Stopper ${ }^{\circledR}$ (ABS) is a unique folkloric medicinal plant extract. ABS has been approved in the management of external hemorrhage and dental surgery by the Ministry of Health in Turkey.

Exposure to ABS results in a very rapid formation of network within the plasma and serum. The basic mechanism of action of ABS is through the formation of an encapsulated protein network. ${ }^{[5]}$ The ABS-induced protein network formation involves blood cells, especially erythrocytes, without affecting the physiological individual coagulation systems. ${ }^{[5]}$ ABS is a standardized extract from the following plants: Glycyrrhiza glabra, Vitis vinifera, Alpinia officinarum, Urtica dioica, and Thymus vulgaris, in a weight ratio of 9:8:7:6:5, respectively. ${ }^{[5,6]}$ Alpinia officinarum inhibits nitric oxide production by lipopolysaccharide-activated mouse peritoneal macrophages. ${ }^{[7]}$ Urtica dioica causes vasodilatation via inducing nitric oxide production by the endothelium. ${ }^{[8]}$ Glycyrrhiza glabra has anti-inflammatory, anti-thrombin, anti-platelet, anti-oxidant, anti-atherosclerotic, and anti-tumor activities. It inhibits angiogenesis and decreases vascular endothelial growth factor production and cytokine-induced neovascularization. ${ }^{[9]}$ Thymus vulgaris has anti-oxidative actions, such as prevention of lipid peroxidation. ${ }^{[10]}$ Vitis vinifera exerts anti-tumor and anti-atherosclerotic effects. ${ }^{[11,12]}$ Thus, the mechanisms underlying the hemostatic control by ABS have been investigated thoroughly in many studies.

ABS induced very rapid ( $<1$ second) formation of a cellular protein network especially through vital erythroid aggregates within the plasma and serum samples. ${ }^{[13]}$ ABS has no toxic reactions when applied to mucosal surfaces like the mouth and through the gastrointestinal tract. ${ }^{[13-17]}$ However, the effects of longterm and deep tissue exposure to ABS remain unclear in these studies.
Since the histopathological effect of ABS at the deep tissue level and the result of the dark clot created are not adequately known at present, this study aimed to investigate the basic histopathological changes under light microscope in deep tissue injuries as well as remote organs when ABS is applied deeply in the tissues and to determine if the dark clot is reabsorbed after two weeks. In this study, we compared two forms of ABS (spray and tampon) with Surgicel.

\section{MATERIALS AND METHODS}

This is an open-label trial of ABS in a rat model of femoral vein puncture. A total of 50 Wistar Albino adult (280-320 g) female rats were used in this study. The animals were kept in a room at a constant temperature of $22 \pm 1{ }^{\circ} \mathrm{C}$ and fed with standard pellet chow, and the room was maintained on a 12-hour light/dark cycle. Food and water were available ad libitum. All experiments were performed in conformity with the European Community Council Directive. This experimental study was carried out in the animal research laboratory of a university hospital and was approved by the Kahramanmaras Sutcu Imam University Medical Faculty Animal Ethics Committee.

The rats were divided into five groups of 10 rats each. The animals were anesthetized intraperitoneally with combinations of ketamine $(60 \mathrm{mg} / \mathrm{kg})$ and xylazine $(10 \mathrm{mg} / \mathrm{kg})$. Each group except Group 5 underwent femoral vein puncture with a needle $0.6 \mathrm{~mm}$ in diameter in the middle part of the femoral vein after skin incision and tissue dissection (Fig. 1a).

The tampon group treated with ABS tampon underwent the conventional technique with hemostatic agent application (approximately $0.5 \mathrm{~cm} 2 \mathrm{ABS}$ tampon [containing $\sim 0.9 \mathrm{ml}$ ] was placed on the punctured vein region for 30 seconds with mild pressure) (Fig. 1b). The spray group was treated with ABS spray (containing $0.1 \mathrm{ml}$ per pump). The Surgicel group was treated with Surgicel (approximately $0.5 \mathrm{~cm}^{2}$ ) (Fig. 1c), and the animals in the control group were left without any treatment for bleeding after puncturing the vein; a spontaneously formed clot limited the bleeding. The sham group underwent only skin and tissue dissection. After treatment, all rats underwent simple closure with $3 / 0$ silk suture. All rats survived through 14 days and were fed and kept in the same conditions as before the experimental study. The rats were sacrificed by overdose anesthesia on the 14th day. Then, each group underwent partial tissue excision in the same femoral region (including femoral artery, vein and nerve) that had been treated with ABS and Surgicel two weeks before. In addition, samples were also obtained from the brain, heart, kidney, and liver to investigate the remote organ effects of ABS. All specimens were kept in 10\% neutral formaldehyde solution. Tissue specimens were prepared after routine procedures and then embed- 

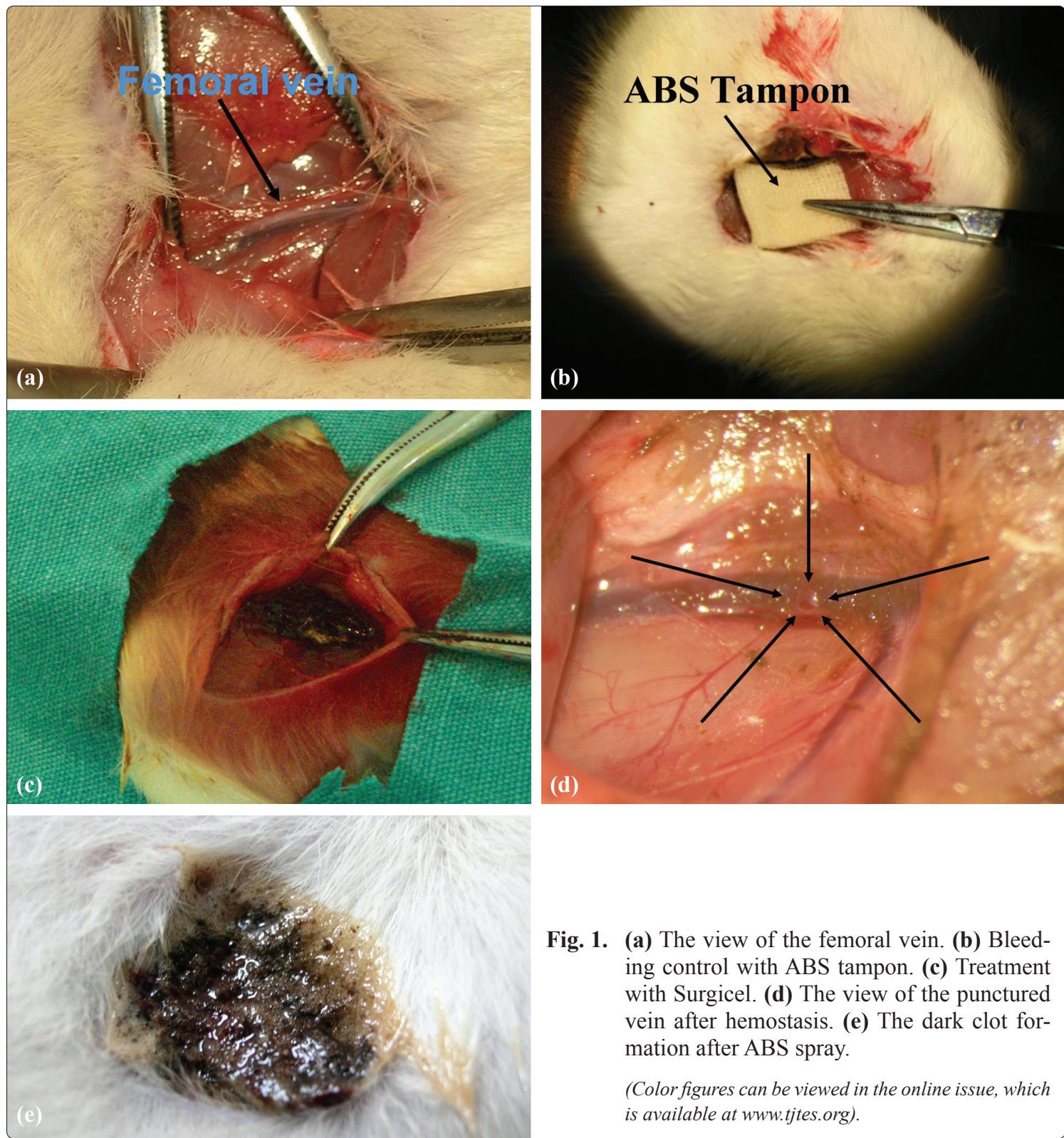

Fig. 1. (a) The view of the femoral vein. (b) Bleeding control with ABS tampon. (c) Treatment with Surgicel. (d) The view of the punctured vein after hemostasis. (e) The dark clot formation after ABS spray.

(Color figures can be viewed in the online issue, which is available at www.tjtes.org).

ded in paraffin. Sections $(5 \mu \mathrm{m})$ were prepared from all specimens and stained with hematoxylin and eo$\sin (\mathrm{H} \& \mathrm{E})$. All specimens were evaluated under light microscope histopathologically and photographs were taken (H\&Ex40, H\&Ex100, H\&Ex200) by a pathologist blinded to the study groups. Light microscopic findings were graded semi-quantitatively from 0 (no histopathological change) to +3 (severe histopathological change). This histopathological grading was performed for perivascular connective tissue as acute inflammation, chronic inflammation, hemosiderinloaded macrophages, fibrosis, and necrosis by using the four-point scale of Bautista et al. ${ }^{[18]}$

\section{Statistical analysis}

Statistical analyses were carried out using the Statistical Package for the Social Sciences (SPSS) soft- ware (v. 16.0 for Windows, SPSS Inc.; Chicago, IL). All values were expressed as means $\pm \mathrm{SD}$. $p$ values less than 0.05 were assumed to be statistically significant. Group comparisons were made by Kruskal-Wallis analysis, followed, in cases of significance, by the Mann-Whitney U-test.

\section{RESULTS}

In this study, cessation of bleeding was achieved successfully after ABS tampon application to the punctured vein in the tampon group (Group 1). The ABS tampon took the excess clot after removal, and the hemorrhage area remained clear; the defective vein was closed with a wall-like clot formation without any sign of leakage (Fig. 1d). In the spray group (Group 2), after application of ABS spray to the fresh blood pool, a dark clot mass was formed very rapidly, 
which closed the view of the punctured vein, but it also achieved the presumed purpose in a very short time after the spray application (Fig. 1e). In Group 3, Surgicel also stopped the bleeding. Group 4 was left

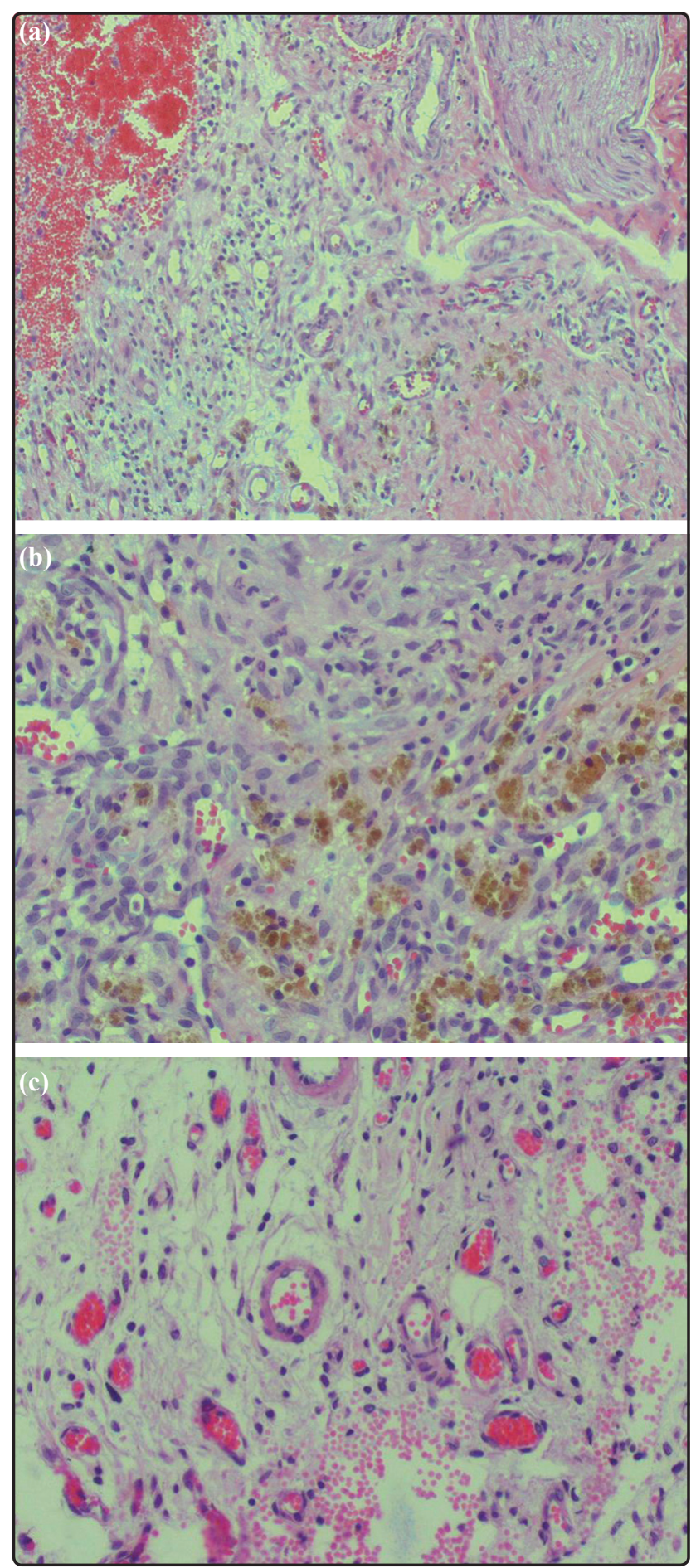

Fig. 2. (a) The microscopic view of the tampon group after two weeks. (b) The microscopic view of the spray group after two weeks. (c) The microscopic view of the Surgicel group after two weeks.

(Color figures can be viewed in the online issue, which is available at www.tjtes.org). untreated after the puncture, and bleeding stopped spontaneously following a huge clot mass (Fig. 1c). After two weeks, no animals were lost. The animals were examined twice a day for local-systemic infection or regional hematoma, and none occurred in either the treated groups or the controls. All rats survived without any complication. The rats underwent incision in the same area two weeks after sacrificed with overdose anesthetics. In the tampon group, the macroscopic view was clear without any remarkable fibrosis or adhesion. In the spray group, there was a petechia-like appearance in the ABS spray-applied area. In the Surgicel group, Surgicel was absorbed and there were no signs of adhesion or fibrosis in the macroscopic view. In the control group, a hematoma formation-like appearance was seen in the macroscopic observation, while in the baseline group (sham), the macroscopic tissue appearance was normal.

After collecting the specimens from the brain, heart, kidney, and liver of each group, they were examined under light microscope to determine any histopathological changes. The neurovascular structures from the femoral region in all groups and remote organs remained normal. The specimens from the femoral region, especially the connective tissues, were also examined in all groups under light microscope, and the results are respectively mentioned. Light microscopic findings in the perivascular connective tissue of the rats on the 14th day are shown in Table 1. In the tampon group, the specimen included mild chronic inflammatory and hemosiderin-loaded cells and mild fibrosis in perivascular connective tissue, without any finding of cell degeneration or necrosis (Fig. 2a). In the spray group, the specimen included mild acute inflammatory and moderate chronic inflammatory cells, and moderate hemosiderin-loaded macrophages and moderate fibrosis were observed in the perivascular connective tissue; however, neurovascular structures remained normal (Fig. 2b). There were significant differences in acute inflammatory cells, hemosiderinloaded macrophages and fibrosis between the tampon and spray groups $(p<0.05)$. There were mild chronic inflammatory cells and hemosiderin-loaded macrophages in the perivascular connective tissue in the Surgicel group (Fig. 2c). While there was no statistical difference in any of the findings between the Surgicel and tampon group $(p>0.005)$, in contrast, there were significant differences between the Surgicel and spray groups in acute inflammation and hemosiderin-loaded macrophages $(p<0.05)$. In the control group, the specimens included apparent congestion in vessels, and mild acute inflammatory cells and mild fibrosis were observed in the perivascular connective tissue. A comparison of the control group with the tampon, spray and Surgicel groups revealed that there were significant differences in all findings $(\mathrm{p}<0.05)$ except 
Table 1. The mean values of inflammation

\begin{tabular}{lccccc}
\hline \multirow{2}{*}{ Histopathological changes } & \multicolumn{5}{c}{ Groups } \\
\cline { 2 - 6 } & $\begin{array}{c}\text { Tampon } \\
\text { Mean } \pm \text { SD }\end{array}$ & $\begin{array}{c}\text { Spray } \\
\text { Mean } \pm \text { SD }\end{array}$ & $\begin{array}{c}\text { Surgicel } \\
\text { Mean } \pm \text { SD }\end{array}$ & $\begin{array}{c}\text { Control } \\
\text { Mean } \pm \text { SD }\end{array}$ & $\begin{array}{c}\text { Sham } \\
\text { Mean } \pm \text { SD }\end{array}$ \\
\hline Necrosis & None & None & None & None & None \\
Acute inflammation & $0.3 \pm 0.95$ & $0.7 \pm 0.48$ & $0.0 \pm 0.00$ & $1.2 \pm 0.42$ & $0.2 \pm 0.42$ \\
Chronic inflammation & $1.3 \pm 0.48$ & $1.6 \pm 0.52$ & $1.2 \pm 0.42$ & $0.2 \pm 0.42$ & $0.8 \pm 0.42$ \\
Hemosiderin - loaded macrophage & $0.8 \pm 0.63$ & $2.4 \pm 0.52$ & $1.3 \pm 1.06$ & $0.2 \pm 0.42$ & $0.2 \pm 0.42$ \\
Fibrosis & $1.1 \pm 0.74$ & $2.0 \pm 0.47$ & $1.7 \pm 1.25$ & $0.5 \pm 0.53$ & $0.5 \pm 0.53$ \\
\hline
\end{tabular}

$0=$ None; $1=$ Mild; $2=$ Moderate; $3=$ Severe.

fibrosis in the tampon group, and there were significant differences in all findings between the spray and Surgicel groups. In the baseline group (sham), there were mild chronic inflammatory cells and mild fibrosis in the perivascular connective tissue. There were significant differences in acute and chronic inflammatory cells $(p<0.05)$, but no difference in hemosiderinloaded macrophages and fibrosis $(\mathrm{p}>0.05)$, between the sham and control groups. There were significant differences in chronic inflammatory cells and hemosiderin-loaded macrophages and no difference in acute inflammatory cells and fibrosis between the sham and tampon groups. There were significant differences in all findings between the sham and spray groups. There were significant differences in hemosiderin-loaded macrophages and fibrosis and no difference in acute and chronic inflammatory cells between the sham and Surgicel groups. Comparisons of the histopathological changes in groups are shown in Table 2.

\section{DISCUSSION}

Ankaferd Blood Stopper ${ }^{\circledR}$ (ABS) has been used to stop hemorrhage on skin surfaces, during dental procedures and on internal surfaces in many cases, without any toxic reaction, but there has been no investigation regarding the histopathological long-term effects in tissues. The clinical observations and macroscopic appearance of the applied area are enough to prove the safety of ABS. ${ }^{[14-17,19-21]}$ The recent data, especially in animal-based studies, have shown the efficacy and non-toxicity of ABS in the management of hemorrhage. ${ }^{[4,5,22-24]}$ In vitro data on the anti-infective characteristic of ABS and preliminary successful applications in the gastrointestinal tract and dental bleedings have represented incoming clues regarding $\mathrm{ABS}$ activity. ${ }^{[19,20,22,25]}$

In this study, we planned an animal model of femoral venipuncture in which different methods of ABS application were compared with Surgicel, and we also investigated the histopathological changes with respect to the long-term effects of the plant extracts (mixed in a prescribed ratio) on regional and systemic tissues in rats. After puncturing the vein, application of ABS rapidly stopped the bleeding in both forms of tampon and spray (in 1 second), and the excess forma-

Table 2. The $p$ values of results of comparisons between the groups according to acute and chronic inflammatory cells, macrophages and fibrosis

\begin{tabular}{lccccc}
\hline & \multicolumn{3}{c}{ Histopathological changes } \\
\cline { 2 - 5 } Groups & $\begin{array}{c}\text { Acute } \\
\text { Inflammation }\end{array}$ & $\begin{array}{c}\text { Chronic } \\
\text { Inflammation }\end{array}$ & $\begin{array}{c}\text { Hemosiderin - loaded } \\
\text { macrophage }\end{array}$ & Fibrosis & Necrosis \\
\hline Tampon - Spray & 0.020 & 0.189 & 0.000 & 0.006 & N/A \\
Tampon - Surgicel & 0.317 & 0.615 & 0.247 & 0.181 & N/A \\
Tampon - Control & 0.001 & 0.000 & 0.025 & 0.062 & N/A \\
Tampon - Sham & 0.626 & 0.028 & 0.025 & 0.062 & N/A \\
Spray - Surgicel & 0.001 & 0.075 & 0.014 & 0.897 & N/A \\
Spray - Control & 0.028 & 0.000 & 0.000 & 0.000 & N/A \\
Spray - Sham & 0.028 & 0.003 & 0.000 & 0.000 & N/A \\
Surgicel - Control & 0.000 & 0.000 & 0.012 & 0.029 & N/A \\
Surgicel - Sham & 0.146 & 0.051 & 0.012 & 0.029 & N/A \\
Control - Sham & 0.000 & 0.009 & 1.000 & 1.000 & N/A \\
\hline
\end{tabular}

N/A: Not applicable. 
tion of the formed black clot was remarkable in the spray group. Examination of the specimens that underwent ABS application in both forms of tampon and spray under light microscope revealed no histopathological toxicity, cell degeneration or necrosis even after two weeks.

Inflammation is a protective response intended to eliminate the initial cause of cell injury as well as the necrotic cells and tissues resulting from the original insult. Acute inflammation is rapid in onset and of short duration, lasting from a few minutes to as long as a few days, and is characterized by fluid and plasma protein exudation and a predominantly neutrophilic leukocyte accumulation. If the injurious agent cannot be eliminated quickly, the result may be chronic inflammation. Chronic inflammation may be more insidious, is of longer duration (days to years), and is typified by an influx of lymphocytes and macrophages with associated vascular proliferation and fibrosis (scarring). ${ }^{[26]}$

In our study, as we compared the groups, there was mild inflammation in all groups except the spray group. Only the spray group differed from the other groups, and the difference in severity of inflammation was statistically significant $(p<0.05)$; while the inflammation severity was moderate in the spray group, there was only mild inflammation in the other groups. The reason for this difference may be the excessive use of ABS spray. When using the ABS tampon to stop bleeding, the tampon contacts the hemorrhagic surface and leaves minimal residue of the ABS extract (the approximately $0.5 \mathrm{~cm}^{2}$ of ABS tampon contained $0.09 \mathrm{ml}$ extract). However, in ABS spray form, approximately $0.1 \mathrm{ml}$ of $\mathrm{ABS}$ extract was sprayed onto the hemorrhagic area. The amount of blood clot seems to be irrelevant because there was a significant difference between the spray and control group $(p<0.001)$ in all findings except acute inflammatory cells. This may result from the amount of ABS extract used. Acute inflammation may progress to chronic inflammation when the acute response cannot be resolved. ${ }^{[26]}$ Because of the greater amount of ABS used in spray form than tampon, the inflammation might have progressed to chronic inflammation, and hemosiderinloaded macrophages were the dominant cells that were clearing the injured area from clot and plant extract.

In a recent study, Odabaş et al. ${ }^{[27]}$ found that ABS was cytotoxic to human pulp fibroblasts. The sensitivity of cytotoxicity depended on the concentration of the material tested. The greater dilutions exhibited less cytotoxicity compared to the more concentrated forms of ABS extract. This new study supports our findings that higher concentrations of ABS may result in more severe inflammatory reaction in the perivascular connective tissue. However, there were no signs of ne- crosis or cell degeneration in any of the groups in our study that demonstrated cytotoxicity. This result needs to be investigated further.

In one study, ABS was used in the damaged bladder wall in rats. Similar to our study, the authors found that there were no toxic reactions or fibrosis after two weeks. ${ }^{[23]}$

In another study, no acute mucosal toxicity, hematotoxicity, hepatotoxicity, nephrotoxicity, or biochemical toxicity was observed during the short-term follow-up of the animals when ABS was applied to internal topical surfaces. ${ }^{[28]}$ Neither local nor systemic adverse effects or toxicity were observed in association with experimental and anecdotal topical application of ABS. ABS may offer a valuable option due to its ease of application and speed of action; it does not require precise localization to the bleeding site. Simple topical application and easy use over the hemorrhagic area was able to stop the bleeding. ${ }^{[17]}$

A double-blinded, randomized, placebo-controlled, crossover phase I clinical study with a five-day washout period between the crossover periods demonstrated the safety of topical ABS administration in healthy human volunteers. Following these findings, it was concluded that topical application of ABS is safe. ${ }^{[29]}$ Further investigations in control of the bleeding with application of ABS could shed light regarding safer use in clinical conditions.

The effects of ABS on vascular endothelium, blood cells, angiogenesis, cellular proliferation, vascular dynamics, and cellular mediators are being investigated currently to determine its potential role in many pathological states and tissue repair. ${ }^{[30,31]}$ These results are promising regarding the non-toxicity of ABS in the use of traumatic hemorrhage in deep tissues.

In conclusion, based on its hemostatic actions, ABS, a traditional folkloric medicinal plant extract, could be a candidate for use in clinical medicine in pre-hospital settings after trauma pending its ability to reduce blood loss and increase survival and in the management of patients with coagulopathy disorders or using anticoagulant-antiaggregant drugs. ABS successfully stopped hemorrhage in deep tissue traumas locally. No pathological changes were determined under light microscopic examination two weeks later. We conclude that ABS can be used safely since it does not lead to any degeneration of regional and systemic tissues, but there is a need for further investigations in human models.

\section{Acknowledgement}

This experimental study was supported by Kahramanmaras University Council of Experts (decision 2009/4-8 m). 
Conflict-of-interest issues regarding the authorship or article: None declared.

\section{REFERENCES}

1. Sauaia A, Moore FA, Moore EE, Moser KS, Brennan R, Read RA, et al. Epidemiology of trauma deaths: a reassessment. J Trauma 1995;38:185-93.

2. Edward E. Cornwell III. Initial approach to trauma. In: Tintinalli JE, Kelen GD, Stapczynski JS, Ma OJ, Cline DM, editors. Emergency medicine: a comprehensive study guide. New York, NY: McGraw-Hill; 6th ed. 2004. p. 1537-42.

3. Teller P, White TK. The physiology of wound healing: injury through maturation. Surg Clin North Am 2009;89:599-610.

4. Cipil HS, Kosar A, Kaya A, Uz B, Haznedaroglu IC, Goker $\mathrm{H}$, et al. In vivo hemostatic effect of the medicinal plant extract Ankaferd Blood Stopper in rats pretreated with warfarin. Clin Appl Thromb Hemost 2009;15:270-6.

5. Goker H, Haznedaroglu IC, Ercetin S, Kirazli S, Akman U, Ozturk Y, et al. Haemostatic actions of the folkloric medicinal plant extract Ankaferd Blood Stopper. J Int Med Res 2008;36:163-70.

6. Ankaferd web site. Available at: http://www.ankaferd.com/ eng/abs-formul.php Accessed March 20, 2010.

7. Matsuda H, Ando S, Kato T, Morikawa T, Yoshikawa M. Inhibitors from the rhizomes of Alpinia officinarum on production of nitric oxide in lipopolysaccharide-activated macrophages and the structural requirements of diarylheptanoids for the activity. Bioorg Med Chem 2006;14:138-42.

8. Testai L, Chericoni S, Calderone V, Nencioni G, Nieri P, Morelli I, et al. Cardiovascular effects of Urtica dioica L. (Urticaceae) roots extracts: in vitro and in vivo pharmacological studies. J Ethnopharmacol 2002;81:105-9.

9. Sheela ML, Ramakrishna MK, Salimath BP. Angiogenic and proliferative effects of the cytokine VEGF in Ehrlich ascites tumor cells is inhibited by Glycyrrhiza glabra. Int Immunopharmacol 2006;6:494-8.

10. Lee SJ, Umano K, Shibamoto T, Lee KG. Identification of volatile components in basil (Ocimum basilicum L.) and thyme leaves (Thymusvulgaris L.) and thei antioxidant properties. Food Chem 2005;91:131-7.

11. Zhao J, Wang J, Chen Y, Agarwal R. Anti-tumor-promoting activity of a polyphenolic fraction isolated from grape seeds in the mouse skin two-stage initiation-promotion protocol and identification of procyanidin B5-3'-gallate as the most effective antioxidant constituent. Carcinogenesis 1999;20:1737-45.

12. Yamakoshi J, Kataoka S, Koga T, Ariga T. Proanthocyanidinrich extract from grape seeds attenuates the development of aortic atherosclerosis in cholesterol-fed rabbits. Atherosclerosis 1999;142:139-49.

13. Haznedaroglu BZ, Haznedaroglu IC, Walker SL, Bilgili H, Goker H, Kosar A, et al. Ultrastructural and morphological analyses of the in vitro and in vivo hemostatic effects of Ankaferd Blood Stopper. Clin Appl Thromb Hemost 2010;16:446-53.

14. Kurt M, Oztas E, Kuran S, Onal IK, Kekilli M, Haznedaroglu IC. Tandem oral, rectal, and nasal administrations of Ankaferd Blood Stopper to control profuse bleeding leading to hemodynamic instability. Am J Emerg Med 2009;27:631. e1-2.

15. Teker AM, Korkut AY, Gedikli O, Kahya V. Prospective, controlled clinical trial of Ankaferd Blood Stopper in children undergoing tonsillectomy. Int J Pediatr Otorhinolaryngol 2009;73:1742-5.

16. Kurt M, Kacar S, Onal IK, Akdogan M, Haznedaroglu IC. Ankaferd Blood Stopper as an effective adjunctive hemostatic agent for the management of life-threatening arterial bleeding of the digestive tract. Endoscopy 2008;40:E262.

17. Kurt M, Akdogan M, Onal IK, Kekilli M, Arhan M, Shorbagi A, et al. Endoscopic topical application of Ankaferd Blood Stopper for neoplastic gastrointestinal bleeding: A retrospective analysis. Dig Liver Dis 2010;42:196-9.

18. Bautista A, Tojo R, Varela R, Estevez E, Villanueva A, Cadranel S. Effects of prednisolone and dexamethasone on alkali burns of the esophagus in rabbit. J Pediatr Gastroenterol Nutr 1996;22:275-83.

19. Kurt M, Disibeyaz S, Akdogan M, Sasmaz N, Aksu S, Haznedaroglu IC. Endoscopic application of ankaferd blood stopper as a novel experimental treatment modality for upper gastrointestinal bleeding: a case report. Am J Gastroenterol 2008;103:2156-8.

20. Dogan OF, Ozyurda U, Uymaz OK, Ercetin S, Haznedaroglu IC. New anticoagulant agent for CABG surgery. Eur J Clin Invest 2008;38:341.

21. Ibis M, Kurt M, Onal IK, Haznedaroglu IC. Successful management of bleeding due to solitary rectal ulcer via topical application of Ankaferd blood stopper. J Altern Complement Med 2008;14:1073-4.

22. Bilgili H, Kosar A, Kurt M, Onal IK, Goker H, Captug O, et al. Hemostatic efficacy of Ankaferd Blood Stopper in a swine bleeding model. Med Princ Pract 2009;18:165-9.

23. Kilic O, Gonen M, Acar K, Yurdakul T, Avunduk MC, Esen $\mathrm{HH}$, et al. Haemostatic role and histopathological effects of a new haemostatic agent in a rat bladder haemorrhage model: an experimental trial. BJU Int 2010;105:1722-5.

24. Kosar A, Cipil HS, Kaya A, Uz B, Haznedaroglu IC, Goker $\mathrm{H}$, et al. The efficacy of Ankaferd Blood Stopper in antithrombotic drug-induced primary and secondary hemostatic abnormalities of a rat-bleeding model. Blood Coagul Fibrinolysis 2009;20:185-90.

25. Akkoc N, Akcelik M, Haznedaroglu I, Goker H, Aksu S, Kirazli S, et al. In vitro antibacterial activities of Ankaferd Blood Stopper. Int J Lab Hematol 2008;30:95.

26. Kumar V, Abbas AK, Fausto N, Mitchell R (editors). Robbins basic pathology. Saunders, Elsevier; 8th ed. 2007

27. Odabaş ME, Ertürk M, Çınar Ç, Tüzüner T, Tulunoğlu Ö. Cytotoxicity of a new hemostatic agent on human pulp fibroblasts in vitro. Med Oral Patol Oral Cir Bucal 2011;16:e5847.

28. Bilgili H, Captug O, Kosar A, Kurt M, Kekilli M, Shorbagi A, et al. Oral systemic administration of Ankaferd blood stopper has no short-term toxicity in an in vivo rabbit experimental model. Clin Appl Thromb Hemost 2010;16:533-6.

29. Adouble-blinded, randomized, placebo-controlled, crossover phase I clinical study of Ankaferd Blood Stopper. ANKAFERD Blood Stopper Investigational Drug Research Activities Report. 2008. p. 66-74.

30. Huri E, Akgül T, Ayyildiz A, Ustün H, Germiyanoğlu C. Hemostatic role of a folkloric medicinal plant extract in a rat partial nephrectomy model: controlled experimental trial. J Urol 2009;181:2349-54.

31. Haznedaroglu IC. Molecular basis of the pleiotropic effects of Ankaferd Blood Stopper. IUBMB Life 2009;61:290. 